\title{
Social License and Environmental Protection: Why Businesses Go Beyond Compliance
}

\author{
Neil Gunningham, \\ Robert A. Kagan, and Dorothy Thornton
}

This article examines the concept of the corporate "social license," which governs the extent to which a corporation is constrained to meet societal expectations and avoid activities that societies (or influential elements within them) deem unacceptable, whether or not those expectations are embodied in law. It examines the social license empirically, as it relates to one social problem - environmental protection-and as it relates to one particular industry: pulp and paper manufacturing. It shows why the social license is important, the circumstances in which it may encourage companies to go "beyond compliance" with regulation, how its terms are monitored and enforced, and how it interacts with what we term the regulatory and economic licenses. Overall, this research demonstrates that corporate environmental behavior cannot be explained purely in terms of instrumental threats and moral obligations to comply with the law, and that the increasing incidence of "beyond compliance" corporate behavior can be better explained in terms of the interplay between social pressures and economic constraints.

Neil Gunningham holds professorial research appointments in the Regulatory Institutions Network, Research School of the Social Sciences, and the School of Resources, Environment, and Society at the Australian National University. Robert A. Kagan is professor of political science and law at the University of California, Berkeley, and director of the Center for the Study of Law and Society. Dorothy Thornton holds a Ph.D. in health services and policy analysis from the University of California, Berkeley, and currently is a research associate in Berkeley's School of Public Health. The authors are grateful to scores of pulp mill managers, regulatory officials, industry consultants, and environmental activists-all of whom must remain anonymous - for their cooperation and insight. Biyi Abesina provided valuable research assistance. The Center for the Study of Law and Society, University of California, Berkeley, provided space, administrative assistance, and social support for the research project that led to this article, and the Smith Richardson Foundation provided primary funding for our research. This article draws on research and analysis previously published in Gunningham, Kagan, and Thornton 2003 and Kagan, Gunningham, and Thornton 2003. 
Traditionally, corporations that complied with the dictates of applicable legislation regarded not just their legal but also their social obligations as ending at that point. Sociolegal research suggested that corporations complied with law only for instrumental reasons (to avoid legal penalties) (Hawkins and Hutter 1993) or because, "regulations are taken to be a measure of societal expectations, and thus interpreted as a guide to an organization's moral and social duties" (Wright 1998, 14). From this traditional point of view, corporations could be expected to take actions that went "beyond compliance" only where they saw some financial selfinterest in doing so, such as increasing profit, usually over the short term (Porter and Van der Linde 1995).'

Today, however, at least in economically advanced democracies, many corporations no longer perceive their social obligations as necessarily synonymous with their legal obligations. Two decades of tightening regulatory rules and legal threats have led many businesspeople to assume that any hazards and harms that their enterprise engenders, even if not clearly illegal today, will sooner or later be subject to public censure, government action, and legal liability. Community groups and nongovernment organizations (NGOs) have also come to play important roles in pressuring corporations to curb their adverse social impacts. In consequence, corporate executives increasingly talk about the importance of operating in accordance with their "social license," meaning that they are constrained to meet the expectations of society and avoid activities that societies (or influential elements within them) deem unacceptable. Thus, for present purposes, we define social license as the demands on and expectations for a business enterprise that emerge from neighborhoods, environmental groups, community members, and other elements of the surrounding civil society. In some instances the conditions demanded by "social licensors" may be tougher than those imposed by regulation, resulting in "beyond compliance" corporate environmental measures even in circumstances where these are unlikely to be profitable. ${ }^{2}$

1. For example, in the case of environment protection, if it was more cost effective for a company to reduce waste than install pollution-abatement equipment, it made economic sense to reduce pollution by investing in waste-reduction methods. Yet until the last decade or so, politicians, environmentalists, and scholars, observing the ongoing degradation of the environment in industrial societies, understandably assumed that the opportunities for such "win-win" investments were few and far between, or at least not prevalent enough. Otherwise there would have been little political demand for government regulation, and for the legal coercion believed to be necessary to compel the vast majority of corporate environmental measures.

2. The fact of substantial over-compliance by the large majority of pulp and paper mills, at least in the United States, has been well documented. As McClelland and Horowitz (1999, 231) conclude from an extensive statistical analysis, "it appears that pulp and paper plants incur substantial materials, energy and labor costs to overcomply with the Clean Water Act. Why they incur these costs is unknown." 
Across the corporate spectrum, there is no consensus on what precisely are the demands of social licensors, how they should be responded to, or if or when they require measures beyond compliance. Nevertheless, a series of damaging encounters between large corporations and institutions of civil society, caused by a corporate misreading of the terms of their social license, has caused a broader corporate rethink. Shell's failure to appreciate public concerns regarding the sinking of the Brent Spar, its oil installation in the North Atlantic, led to costly damage to both its international reputation and sales (Neale 1997). Monsanto's failure to respond to the concerns of European consumers about the introduction of genetically modified food led to a consumer backlash and breakdown of public trust sufficient to cause a restructuring and rebranding of the corporation itself (Moore 2001). And Nike's perceived exploitation of labor in developing countries, widely publicized by a variety of $\mathrm{NGO}$ s operating internationally, also caused substantial damage to its brand image (Connor and Atkinson 1996; van Yoder 2001).

As corporations learn from such reputational disasters and seek to develop more sophisticated risk management strategies, the concept of social license becomes increasingly important in understanding corporate behavior, and in explaining why, in what circumstances, and to what extent corporations may choose to go beyond compliance with their existing legal obligations. It is also a concept of considerable significance to policymakers, opening fruitful possibilities for influencing corporate behavior not just directly through regulation, but also indirectly (and perhaps more powerfully) by empowering various institutions of civil society.

Yet the social license and its policy implications have been the subject of very little empirical study by social scientists, students of regulation, or policymakers. Indeed, the economic, sociolegal, and policy literature on regulatory administration traditionally has focused on explaining corporate compliance and noncompliance with existing legal requirements, tacitly assuming that regulated business corporations take costly measures to meet public policy aspirations only when specifically required to do so by law and when they believe that legal noncompliance is likely to be detected and harshly penalized. ${ }^{3}$ Only recently, and to a limited extent, has a broader literature begun to evolve, particularly in the field of corporate environmental management. ${ }^{4}$

3. See, for example, Becker 1968; Stigler 1970; Miller and Anderson 1986. There is empirical as well as theoretical support for this deterrence-based theory of compliance. According to Regens, Seldon, and Elliott 1997, "We also find that pollution control investment is positively related to the EPA enforcement budget, suggesting at the very least the industries believe that the EPA will increase its investigatory efforts as their budget increases."

4. See, for example, Ghobadian et al. 1998; Reinhardt 2000; Yosie and Herbst 1997; Nash 2000. 
In this article, we examine empirically the role of social license as it relates to one social problem-environmental protection-and as it relates to one particular industry: pulp and paper manufacturing. We show why the social license is important, the circumstances in which it may encourage companies to build in a margin of safety or to go further "beyond compliance," how its terms are monitored and enforced, and how it interacts with what we term the regulatory and economic licenses. Finally, we explore the social policy implications of our findings.

\section{RESEARCH METHODS}

Rather than examining a selection of firms in a variety of industries, we opted for a sector-specific approach because the environmental challenges confronting enterprises, the social forces that bear on them, and their responses are likely to be highly dependent on the characteristics of each particular industry sector.

As we decided which industrial sector to study, the pulp and paper industry presented an attractive option for a number of reasons. Pulp and paper mills, which historically have been sources of extremely serious water pollution and offensive fumes, have been at or near the top of the environmental agenda in every nation in which they operate. Pulp mills' chemical-intensive processes generate visible and serious environmental risks, along with considerable concern from local communities, even in developing countries (Sonnenfeld 2002). And particularly with respect to emissions of dioxin from chlorine-based bleaching processes, the industry has captured the attention of environmental activists, enabling us to examine the influence of these bodies on corporate environmental performance. At the same time, the industry is intensely competitive, plagued by periodical overcapacity, and only intermittently profitable. Firms in the Northern Hemisphere are threatened by lower-cost producers in Southeast Asia, and investors do not see the industry as particularly attractive. Thus, environmental managers in pulp mills have to fight hard for funds for costly environmental measures, especially of the beyond-compliance variety. Moreover, potential environmental innovations by one facility can be copied by others relatively easily, so that the gains from innovation may be short-lived. Finally, it has proved difficult for firms to capture additional market share by creating distinctive, "greener" products. Thus the industry poses a demanding test for the effectiveness of social license demands.

Notwithstanding the economic challenges, in recent years, pulp mills have had a good record of legal compliance. ${ }^{5}$ For the most part, the facilities

5. The EPA's Sector Facility Indexing Project, comparing "significant noncompliance" as detected by inspections and industry reports, found that in 1998 and 1999, American pulp 
in our sample complied with the law, as specified in their regulatory permits. Indeed they overcomplied in some respects, emitting an average of 37 percent of the water pollutants ${ }^{6}$ allowed by their permits. Thus, the industry provides fertile ground for examining whether and how far firms are willing to go beyond compliance, and for determining what factors explain differences among firms in that regard.

Most studies of corporate environmental policies and performance have relied either on (a) structured questionnaires mailed to large number of companies in various lines of commerce ${ }^{7}$ or (b) in-depth case studies of one or two companies, often selected because of their reputation for innovative environmental management. ${ }^{8}$ The survey methodology often suffers from low response rates (which makes the data less representative), ${ }^{9}$ from the researchers' inability to probe general responses for concrete details and reliability, and from variance in the industrial processes and environmental contexts of the respondents. The in-depth case studies rank higher in reliability but are weak in external validity (representativeness) and explanatory power.

In this study, we have charted a middle course, conducting interviewbased studies of 14 facilities (manufacturers of bleached paper pulp) that use a single production technology. Thus we have sought to hold constant (more or less) the nature of the environmental challenges and the economic and technical constraints our respondents face while varying the social contexts within which they operated. The sample is small enough that we were able to conduct lengthy interviews in person, followed in many cases by telephone conversations.

In determining the size of our sample (i.e., the number of firms selected for study), there were inevitably trade-offs to be made between breadth and depth. We were mindful that we wanted a sample size large enough to explore the main variables, but small enough that given resource constraints, we could examine each of our selected firms in sufficient detail to

mills $(N=244)$ had lower levels of significant noncompliance- $4.3 \%$ for clean water regulations, $0 \%$ for RCRA (solid waste), and $21 \%$ for clean air requirements-than most other "dirty" industrial sectors (petroleum and metals manufacturing and smelting) (Stanley 1999). An EPA study of pulp mills in southeastern states in 1982-84 found $6 \%$ in "significant noncompliance" with permit levels, and that four of the 56 mills in the study created most of the instances of significant noncompliance (Magat and Viscusi 1990).

6. Measured by biological oxygen demand and total suspended solids.

7. See, for example, Baylis, Connell, and Flynn (1998) (postal questionnaire to 420 manufacturing and processing companies).

8. See, for example, Hoffman 1997 and Prakash 2000. See also Ghobadian et al. 1998 (survey and analysis of four firms). A more sophisticated methodological approach is taken in Florida, Atlas, and Cline 1999. This involved a much larger number of firms than the orher studies and it also compares matched enterprises. This study, however, has a different focus from our own, being concerned with internal organizational factors.

9. See for example, Greening and Gray 1994 (postal questionnaire to 451 companies) with a $27 \%$ response rate. 
explore key research questions adequately. We chose 15 firms in all: 7 in the United States ( 4 in the state of Washington, 3 in Georgia), 4 in Canada (British Columbia), and 4 in Australia/New Zealand. One of the Australian/New Zealand mills closed before it was possible to obtain adequate data, leaving a total sample size of 14 . All four countries have substantial timber, pulp, and paper industries, and an overall level of economic development and political culture sufficiently similar to provide useful lessons from the others' experience.

In selecting which mills in each jurisdiction to study, we chose not to select them at random, because we wanted to be sure to include some firms that had a reputation for outstanding environmental performance and some that did not. Through preliminary discussions with regulatory officials,

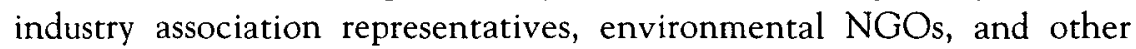
informed sources, we identified facilities with a reputation for excellence. The total number of mills that met our study criteria (same technology) in each jurisdiction were as follows: $\mathrm{BC}=14, \mathrm{GA}=5, \mathrm{WA}=4, \mathrm{NZ}=2$, and AUS $=1$. Of those, we selected all available mills in WA, NZ, and AUS. We then chose 2 mills ( 1 in BC, 1 in GA) for their good environmental reputation. In $\mathrm{BC}$, we deliberately chose 1 mill that was operated by the same parent corporation as 2 U.S. mills already chosen, enabling us to compare the relative impact of corporate management and regulatory jurisdiction. In addition, in $\mathrm{BC}$, we chose 2 mills that had a reputation for being average or below average. ${ }^{10}$ In GA, 2 mills were excluded for difficulty of access reasons. Thus, of the 14 facilities in our sample, 8 were chosen on the basis of their jurisdiction alone, 3 were chosen based on their reputation for excellence, 2 on the basis of their reputation for being average or below average, and 1 because it was owned by the same company as 2 other mills in the study. The sample also includes smaller independent operations as well as mills owned by large transnational corporations.

We conducted lengthy on-site, semi-structured interviews with environmental managers at each sampled facility and, in most cases, with mill managers as well. Our discussions were designed to elicit information about each facility's environmental management and pollution control history, control systems, general approach to environmental problems, and relations with regulators and environmental activists. We probed for specific examples, collecting detailed stories of particular environmental, regulatory, and

10. The sample is reasonably well representative of the range of British Columbian performance, according to official reports of control of chlorine compounds (AOX) in effluent. In 1991, the 14 mills in BC had a range of AOX performance from 0.6 to $6 \mathrm{~kg} / \mathrm{ton}$. The performance of facilities in our sample ranged from 0.6 to $3 \mathrm{~kg} /$ ton and ranked $1 \mathrm{st}, 6 \mathrm{th}$, 9th, and 11th among BC mills. In 1998, the performance of all $14 \mathrm{BC}$ mills ranged from 0.2 to $0.7 \mathrm{~kg} / \mathrm{ton}$. Facilities in our sample ranged from 0.4 to 0.5 , and ranked $3 \mathrm{rd}, 6 \mathrm{th}$, 6 th (a tie), and $12 \mathrm{th}$. 
economic problems, current or past, that illustrated the firm's characteristic response to challenges. ${ }^{11}$

In most cases, we also interviewed officials in corporate headquarters, regulators, and environmental activists familiar with the mills in question. We sought additional perspective on each facility through interviews with industry association officials, environmental consultants, financial analysts, corporate lawyers, other commercial third parties, and on occasion, mill employees. ${ }^{12}$ We achieved a high response rate, partly (we assume) because we provided guarantees of anonymity to our respondents, and partly (we assume) because of the nonconfidential nature of most of the information being sought. In total, we conducted approximately 70 interviews. In a small minority of cases, where direct contact was not practicable, we conducted telephone interviews. ${ }^{13}$ A brief description of each facility's relationship with the local community is provided in tables 1 and 2 .

\section{THE IMPACT OF THE SOCIAL LICENSE}

The social license is based not on legal requirements but, rather, on the degree to which a corporation and its activities meet the expectations of local communities, the wider society, and various constituent groups. References to the potency of social demands permeated our interviews with pulp mill officials. An environmental manager at an American mill, for example, said,

11. More specifically, in our interviews with pulp mill personnel, we asked, inter alia, what environmental protection actions company personnel were proudest of and why they had taken them; what actions they believed still needed to be taken and why these actions had not yet been taken; how extensively production and environmental management decisions were integrated; how the company evaluated its environmental performance; what specific environmental technology was currently in use at the facility, and when and why it had been installed; what their experience had been with environmental regulators and inspectors; and what their experience had been in relations with host communities and environmental activists concerning environmental issues.

12. We interviewed people from corporate headquarters at 11 out of 14 facilities, regulators at 10 out of 14 facilities, and activists at 6 out of 14 facilities. In some cases, we have conducted follow-up telephone interviews with mill personnel and relevant regulatory officials.

13. Our research on social license formed part of a larger study in which interview-based research was complemented by hard data-primarily measures of water pollutants: total suspended solids (TSS), biological oxygen demand (BOD), and absorbable organic halides $(\mathrm{AOX})$ at most of the mills in our sample. However, we could not meaningfully quantify the intensity of the social pressures each mill experienced. Social license pressures are not merely difficult to measure, but inherently imprecise and malleable. For example, activists demand different things from different mills, and mills employed different ways of responding to, and hence, reshaping, those demands. And the intensity of social pressures depends on how they are interpreted, responded to, and often reshaped by corporate managers. Consequently, we can provide only qualitative evidence concerning the relative importance of firms' social licenses in explaining their environmental performance, and in this article, we refer only tangentially to our hard data (see Kagan, Gunningham, Thornton 2003). 
TABLE 1.

Mills in Relation to Campaigns of Environmental Nongovernmental Organizations (ENGOs)

\begin{tabular}{ll}
\hline Mill & \multicolumn{1}{c}{ Status/subject of ENGO Campaign } \\
\hline AUS & None \\
BC1 & None \\
BC2 & None \\
BC3 & Dioxin and forestry practices \\
BC4 & Forestry \\
GA1 & Dioxin/chlorine \\
GA2 & None \\
GA3 & None \\
NZ1 & None \\
NZ2 & Dioxin and forestry \\
WA1 & None \\
WA2 & None \\
WA3 & None \\
WA4 & None, but Greenpeace tried and failed, thanks to support of local \\
& environmental activists
\end{tabular}

The EPA is such a monolith, it can't adapt. It takes a decade to get something to happen. The environmental community is really setting the tone. It's done far more to make companies accountable for pollution. It does more to keep me on my toes, to give me an incentive to go to my management and say, we have got to do better because the community can sue us and also give us the biggest rewards.

Many pulp mill officials spoke to us quite explicitly about the importance of their social license. As one mill-level environmental manager put it, "It's very important how the community sees the plant; how they are thinking is our license to operate." Another said "If you are going to run the mill in the community you have got to live with them," and yet another remarked, "We have to continuously convince the public we have a right to exist." But what are the demands of civil society?

\section{The Terms of the Social License}

At the most general level, most social actors demand that corporate behavior should not negatively impact human health, the environment, or the enjoyment of property. In the context of mills' discharges, health concerns have focused on minimizing the release of toxic chemicals, particularly dioxin in water discharges, and criteria pollutants in air discharges. Environmental concerns have focused on conventional pollutants 


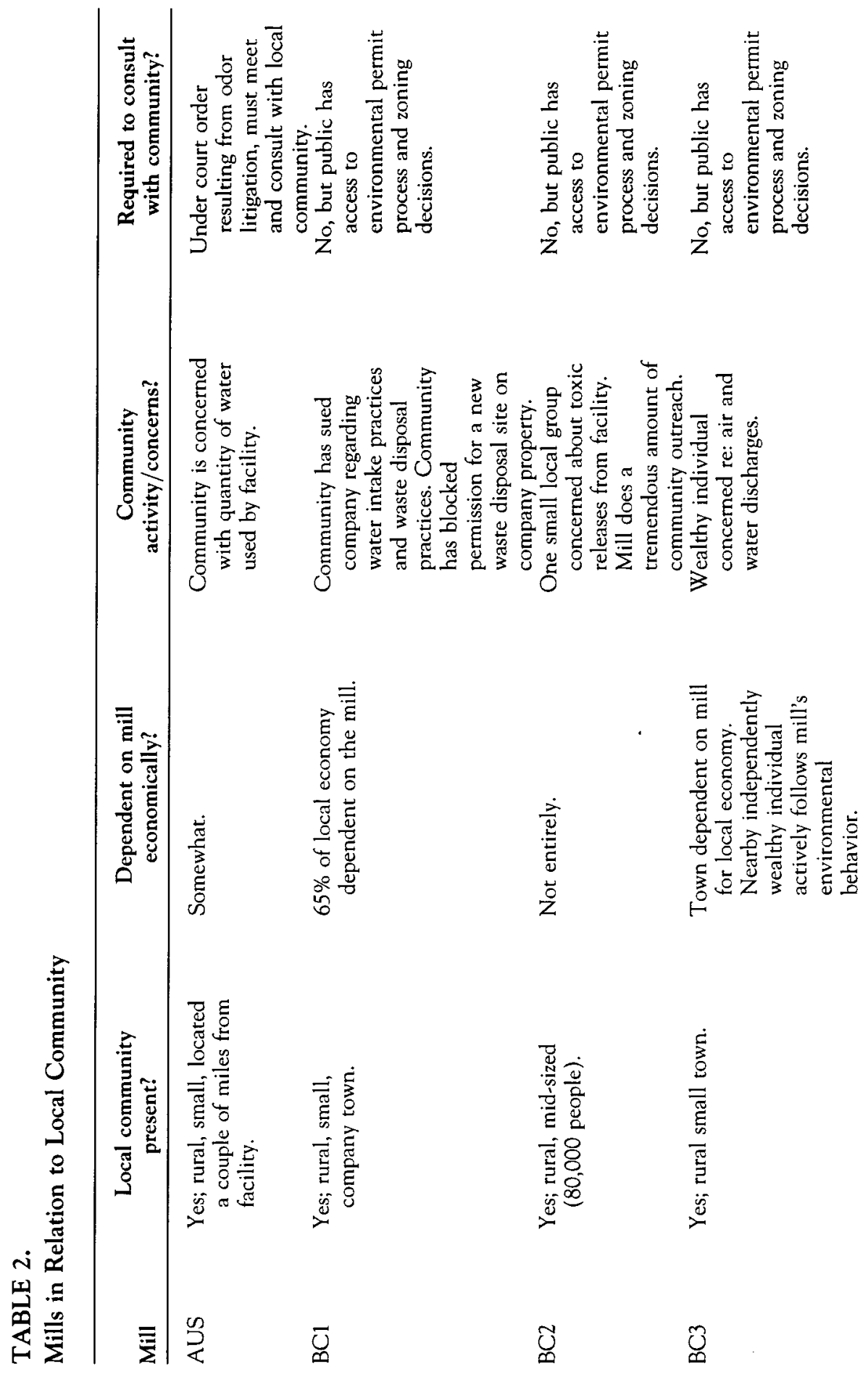




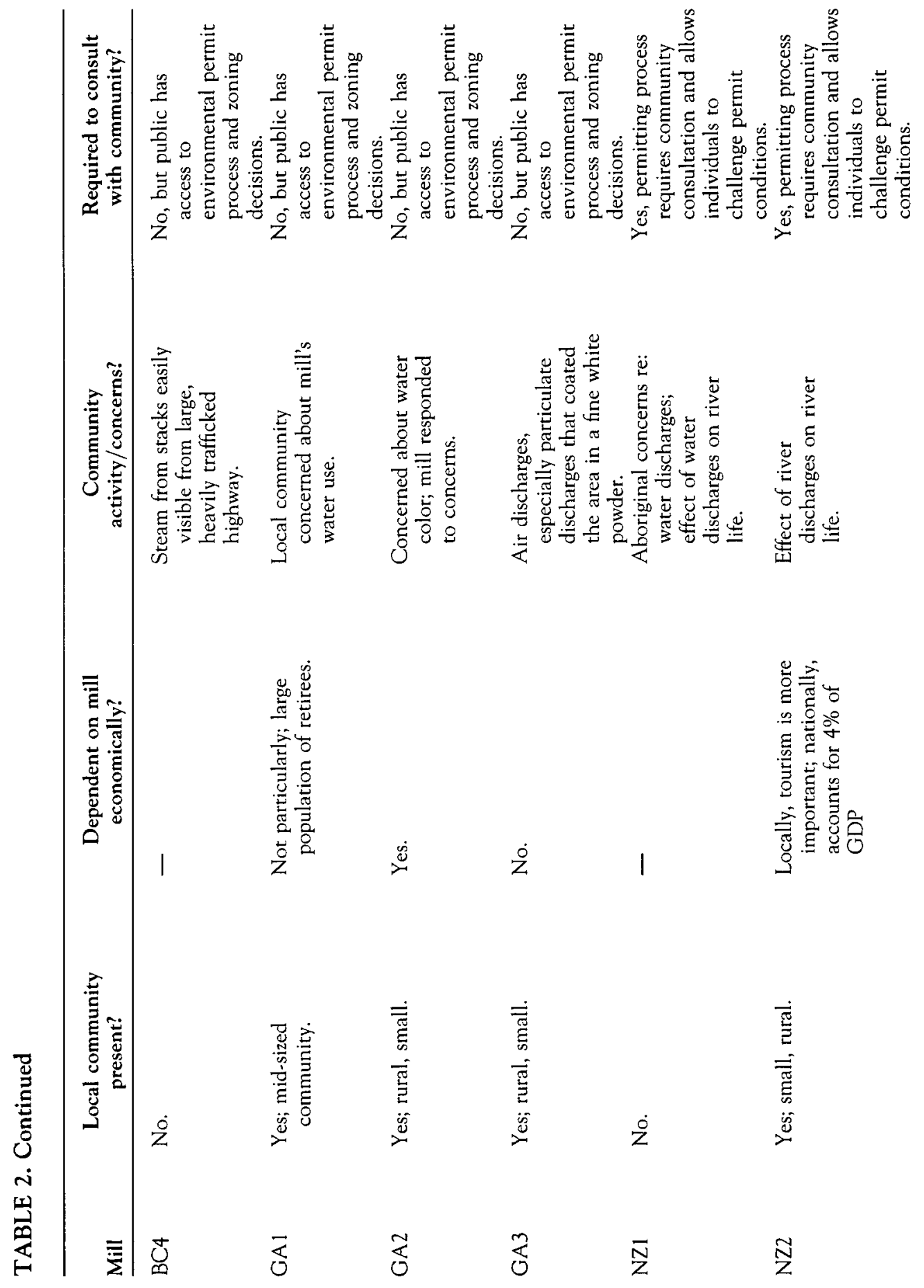




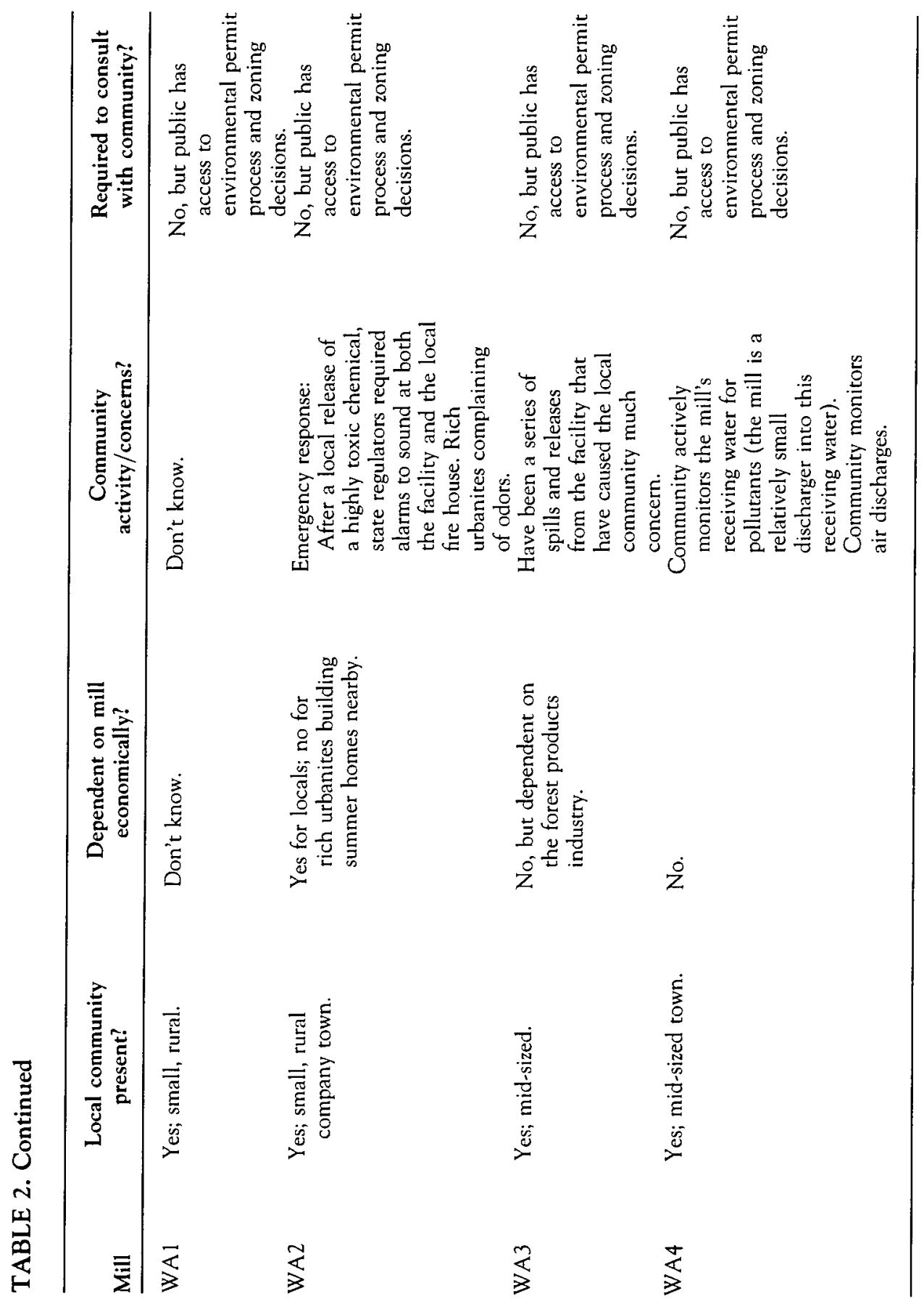


in water discharges. And aesthetic and enjoyment issues have focused on odor, color in water discharges, and steam.

Issues of health and the environment have for the past 30 years been the purview of the legal license, although some social actors, typically environmental nongovernmental organizations (ENGOs), believe legal requirements to be inadequate to protect health and the environment, and therefore demand behavior that extends beyond legal requirements. In the pulp industry, activism by ENGOs has focused primarily on the use of chlorine as a bleaching agent, because it results in emissions of chlorinated organic compounds, particularly the extremely persistent and toxic dioxin. For example, in November 1988, dioxins were discovered in shellfish near a mill in our sample. In highly dramatic public demonstrations, environmental activists targeted the mill's parent company, a forestry company, and the mill itself. By 1989, the mill was spending one billion dollars on modernization and expansion, including reduction of dioxin emissions. In 1991, chlorinated organic emissions from this mill were the lowest for mills of its type in British Columbia.

Whereas ENGOS have focused primarily on the use of chlorine as a bleaching agent, local communities often have made odor control and other aesthetic issues part of pulp mills' social and regulatory licenses. Aesthetic issues have not generally been regulated, except (and only erratically) by tort law. Yet, for many mills, odor control became a major focus. When officials at BC2 were asked, "What are you proudest of in your environmental program?" the unequivocal response was odor reduction:

We used to get $300-350$ odor complaints per year, but now its down to about 50 this year so far. We spent a lot of money to achieve this . . 13 million to put in an odor control system that is not required by law .... But if there is sustained public pressure, we are responsive .... Our behavior is predicated by the feelings of the local community .... We have dedicated scrubbers and a noncondensable gas incinerator system, and we are running at a fraction of what our license permits. The driver is to pacify the community.

We heard very similar stories at a number of other mills: "We didn't have to put in the stripper, but odor is the key to the community .... The only way was to remove it at source, but it wasn't a consent [permit] requirement."

A similar principle was expressed at some mills, such as $\mathrm{BC} 4$, that were highly visible to broader urban as well as local communities (since the mill could be seen by thousands of motorists daily on a busy highway): "The big issue isn't the regulator. It's appearance. It's the steam coming off the stack. This is $99.5 \%$ water, but it's an aesthetic issue. We know that putting in condensers will cost and provide no economic benefits, but it protects our business license." And according to the manager of a pulp mill in a smaller 
town in Georgia (GA2), a decision was made not to fight it as a battle but to understand what the community wanted and to spend money wisely to get the support of the community. For example, water color is not regulated and is not included in the permit so we could have fought about it, but we decided not to. We instilled in ourselves the viewpoint that we wanted to be a good neighbor; it's the local stakeholders that give us the right to operate.

But how can the demands of social actors threaten the very existence of a facility? How are the terms of the social license enforced?

\section{Enforcing the Social License}

The social license can be enforced in a number of significant ways. First, many firms are deeply concerned about preserving their "reputation capital," which the surrounding community can deplete by criticism or expand by praise. The "punishments" and "rewards," current or anticipated, can induce firms to take beyond-compliance measures of the "good citizenship" variety - that is, measures that entail expenditures which are not justified in terms of traditional, quantitative analyses for assessing likely profitability. Rather, good citizen measures are justified on the grounds that enhancing the firm's reputation for good environmental citizenship (and avoiding a reputation for bad environmental citizenship) will in the short or long run be "good business." 14

Second, social license demands can be enforced by augmenting legal enforcement mechanisms, such as pressuring regulators to enforce more vigilantly, and more directly by filing citizen suits. Social actors thereby lend extra enforcement energy and weight to existing regulatory and legal license requirements, pushing regulated enterprises toward full legal complianceand even to investing in beyond-compliance measures that provide a margin of safety ${ }^{15}$ against violations. Thus, as noted earlier, the mills in our sample

14. McClelland and Horowitz (1999) also find that pulp and paper mills overcomply with relevant regulation.

15. Margin-of-safety measures are those that overcomply with current regulations, much as a motorist might drive five miles per hour below the speed limit on a well-policed highway. Thus, many firms construct effluent treatment systems that limit pollutants more stringently than required by regulations or their permits, or that have a larger-than-required capacity, in order to ensure that irregularities or breakdowns in the normal production and treatment operations do not result in a serious violation. Bandyopadhyay and Horowitz (forthcoming) find that randomness leads firms to reduce their average discharges levels below-sometimes far below-their permitted levels, to reduce the chance of an unexpectedly large violation. 
had reduced key pollutants in their effluent well beyond the limits specified in their regulatory permits. ${ }^{16}$

Third, social license demands, if not met, can be translated into new legal requirements. Thus, social license demands can result in a tightening of the regulatory license. And finally, social license demands can be enforced through the market: Customers can impose direct economic costs on noncompliant firms through boycotts, and firms that build a reputation for outstanding environmental performance sometimes can gain price premiums or enhance their position in the labor market. ${ }^{17}$

\section{Affecting Reputation}

This mechanism of social license enforcement relies on the notion of reputation capital. As Joyce and Thomson put it, "Reputation capital represents a communications bridge that predisposes NGOs, communities and other groups to enter into open discussion rather than hostile opposition. Reputation capital carries with it credibility, such that the up-front costs and risk associated with gaining social acceptability are reduced" (Joyce and Thomson 1999). Those with reputation capital, it is argued, will gain readiest access to the means by which to make future profit: development approvals, preferred access to prospective areas and products, the ear of government, the trust of regulators, the tolerance of local communities, and the least risk of being targeted by ENGOs.

One pulp mill environmental manager reflected the same idea-that building reputation capital is a good economic investment-when he told us, in the context of a discussion of local community environmental activists, "You have to develop the relationship in times of peace... [because] ... when there are spills, tank failure, dioxin issues, it gets tough." It was in these circumstances, he argued, that the trust and social capital that had been built up earlier became crucially important. A manager at another mill talked about the pitfalls of failing to build reputation capital: "It works against you when things are behind the community's back. If you have a good relationship with the public, then the goodwill will be there,

16. For mills in the United States and Canada, we were able to compare each mill's BOD and TSS discharges with the legal limits prescribed in their regulatory permits. In 199899 , these nine mills' BOD discharges ranged from 18 to 85 percent of their permit limits, with a mean of 38 percent. For TSS, the range was 14 to 66 percent of permit limits and the mean was 36 percent. No figures for AOX are reported because U.S. permits do not prescribe numeric limits for $\mathrm{AOX}$.

17. We are indebted to an anonymous reviewer for pointing out that personal relationships (plant managers' feelings of personal pride or pressure from friends concerning their plants' environmental performance) could also play a role in enforcing social license demands. However, as this was not a theme raised by our respondents (whereas various other social license enforcement mechanisms were), we do not explore it in this article. 
and when there is trouble you will get the benefit of the doubt. You will have a positive bank account." Regretfully, he added, "We have a zero bank account, or we're in deficit." One consequence of this lack of reputation capital was strong local opposition to the mill's plans for disposal of solid waste, which meant the company faced the prospect of barging the waste, at much greater cost, to a distant disposal site. ${ }^{18}$

Managers at $\mathrm{BC} 4$ told us that the sanction they feared most for breaching regulations were not legal but informal sanctions imposed by the public and the media, and hence, they were motivated less by avoiding regulatory violations per se than by avoiding "anything that could give you a bad name."

At another company (GA1) we talked to in 1999, head-office personnel characterized the company as not having taken environmental issues seriously until a Greenpeace demonstration in which activists scaled the corporate office tower and draped a huge banner with slogans over the front of the building, putting the company and its environmental reputation into the front pages of the newspaper. The corporate officials believed this had been a pivotal event in getting the environment "in the face" of senior management, generating a commitment to improve environmental performance. As one of them put it, "It was the start of a wake up. We have to do more than just crank the mills."

In the examples our respondents gave of overcompliance in response to social license pressures, they were rarely able to provide a precise figure as to how much the extra investment had cost, often because it had become part of some broader technological change (as with dioxin controls). However, it is clear from the examples they gave (e.g., installing odor strippers, steam condensers, technology to control water color) that the expenditure was considerable, sometimes tens of millions of dollars. In many cases, there was no possibility of win-win outcomes through recycling, reducing costs, or developing and selling new technology. Still, this expenditure could not be viewed as economically irrational. On the contrary, mills anticipated substantial (albeit unquantifiable) gains from having permit applications fast tracked, avoiding challenges to future plant expansion, access to new landfill sites, minimizing unanticipated disruptions (e.g., from ENGOs), and (occasionally) protecting export markets. Thus, although an economic rationalist might argue that firms which overcomply cannot continue to operate in a competitive industry (since firms that comply exactly would underprice them), our response would be that, on the contrary, in certain circumstances, they cannot afford to do otherwise.

18. In addition, mill officials were exploring the possibilities for treating the waste to make it a reusable commodity. "Things there might be opportunities," the firm's environmental manager said. Thus, social license pressures can sometimes instigate a search for win-win alternatives. 


\section{Augmenting Legal Enforcement}

Social license demands from local communities, our interviews indicated, have been a primary source of pulp mill progress in reducing the impact of foul odors and other adverse aesthetic impacts, such as discoloration of receiving waters. Social pressures act both directly (as described above) and indirectly, augmenting the enforcement of existing legal pressures by prodding regulators to act early and often. For example, although regulations establish limits on ill-smelling sulfur emissions, ${ }^{19}$ odor control may not in itself be high on a regulator's list, since its environmental impact is minimal (as defined by most regulatory regimes, which emphasize demonstrable adverse effects on human or ecosystem health). But in the case of pulp mills, odor is usually the community's highest priority. In some cases, social pressures drove regulators to use the power of law to demand stronger odor controls. Thus, in Australia, one environmental manager described his mill's prosecution experience as follows:

We have been to court three or four times, and pleaded guilty. We have only argued over the size of the fine. They were all odor-related issues. For example, we had a problem resulting in pulp going into the foul water accumulator and stuffing that up, so it couldn't be pumped into the stripping system so it was discharged down the drain. The nearest private residence is two kilometers away. The towns are five or six kilometers away. It was one of those still, quiet nights, and it stank very badly. It was very apparent what it was. There were lots of complaints to EPA. There was a degree of negligence, but was a prosecution appropriate? We were in a no-win situation. If you cause odor in a residential area, you can't win" (emphasis added).

\section{Tightening Regulatory License Requirements}

In addition to increasing the vigilance with which existing rules are enforced, the demands of social actors can also tighten legal requirements. For example, in 1988, when dioxins were discovered in shellfish downstream from pulp mills in British Columbia, a combination of environmental activism (especially by Greenpeace) and consumer concerns generated sufficient political pressure to result in regulations the following year that tightened conventional pollutant requirements and increased fines for violations. In 1991, a new rule was passed requiring the complete elimination

19. For the United States, 43 Fed. Reg. 7572 (Feb. 23. 1978), as amended at 43 Fed. Reg. 34,785 (Aug. 7, 1978), established emissions limits for total reduced sulfur (TRS) from pulp mills. The EPA's cluster rule characterizes TRS as having health-related as opposed to merely aesthetic impacts. 
of chlorinated organics in pulp mill discharges by December 2002. Greenpeace kept up the pressure in the early 1990s; it organized a consumer boycott of chlorine-bleached paper in Germany, generating demands from some customers for chlorine-free pulp from Canadian producers. At a European port, Greenpeace members painted a 100 -meter long slogan on the hull of a cargo ship carrying pulp and lumber from Canada. The net effect was that in 1991, chlorinated organic discharges from pulp mills in British Columbia equaled 0.6 to $6.0 \mathrm{~kg} / \mathrm{ton}$, but by 1998 -several years before the above-mentioned 2002 legal deadline-the range was 0.2 to 0.72 , an almost 10 -fold decrease in the maximum level of discharge, far in excess of the decrease seen in the United States, where the corporate regulation was not yet formally binding and was somewhat less stringent (and where far fewer companies exported to Europe).

\section{Economic Enforcement}

Because there are no formal means by which to enforce the social license, social licensors seek to do so indirectly by bringing pressure to bear. For example, national and international environmental groups exert pressure largely through the attempt to impose informal economic sanctions. Bad publicity generated by carefully staged media events, such as protestors chaining themselves to pulp barges, or staging public protests in head offices, can impact directly on corporate image and sales and indirectly on share prices and access to investment capital. Thus, when members of an environmental group at a European port painted a derogatory 100-meterlong slogan on the hull of a Canadian cargo ship carrying pulp and lumber, naming the companies involved, this caused not only major embarrassment to one of the companies in our sample but also a threat of boycotts by industrial customers and ultimate consumers.

Sometimes the pressure on the economic license is more direct, as when local community pressure threatens a company's access to essential resources. ${ }^{20}$ For example, one of our sample firms was acutely aware that it was involved in increasingly tough competition for water, that it was perceived as a profligate user of that resource, and that a failure to justify its water use and broader economic contribution to the community could result in a substantial curtailment of its operations. This awareness pervaded many dimensions of the mill's production and environmental program.

Environmental groups also seek to influence customer preferences, sensitizing them to the environmental consequences of the products they buy and urging and orchestrating consumer boycotts. This in turn may affect

20. Such resources include legal resources such as permits to build, permits to operate, and zoning restrictions as well as physical resources, such as energy, water, and lumber. 
the purchasing decisions of buyers of pulp products and directly threaten market access. Thus GA2, which far exceeded the performance of the other American mills in our sample in reducing chlorinated organic emissions, did so in response to European customer concerns regarding dioxin in the diapers it produced, asserting that "it's not good business to be in the middle of the [dioxin] controversy."

Similarly, consumer demand in Europe for chlorine-free paper played a significant role in inducing BC3 - an exporter of market pulp-to make sharp reductions in its AOX emissions during the 1990s, achieving lower levels in 1998-99 than other mills in British Columbia (and indeed, lower than all but one mill in our sample). American pulp mills, on the other hand, generally are not export oriented and hence are more insulated from European demands for chlorine-free and effluent-free paper (Norbert-Bohm and Rossi 1998, 230). With the exception of GA2, with its special customer concerns, the U.S. mills in our sample had below-average records in AOX reduction in 1998-99 (as compared to our sample of mills as a whole). ${ }^{21}$

\section{Variation in the Social License}

Since each community is unique, since each mill's geographical location in relation to its local community differs, and since the degree to which a local community is economically dependent on a mill also differs, so too will the strength and terms of the social license. In practice, we found that all the mills in our sample experienced some community pressure, and in many cases, this was substantial. Nevertheless, almost all our correspondents acknowledged that "location and geography have a lot to do with it" and that a "mill in the boondocks" with an economically dependent local community would be likely to have a more relaxed social license.

In fact, variation between the terms of the social license of mills in our sample often appeared to influence differences in environmental outcomes. ${ }^{22}$ For example, one mill with exemplary environmental performance had a far more demanding social license than another in the same regulatory jurisdiction with relatively lax environmental performance. ${ }^{23}$ The

21. At the same time it is also clear, as noted earlier, that European demand for chlorine-free paper, at least in the late 1990 s, was not so strong as to enable producers to charge a premium for chlorine-free paper. Hence, even mills with the ability to operate chlorine free felt economic pressures to back off from eliminating all AOX, since regulators are still allowing them to do so.

22. We have described elsewhere (Kagan, Gunningham, and Thornton 2003) our attempts to match pairs of companies operating in broadly similar circumstances but with different social license terms.

23. The legal license pressures were presumably the same, both mills being located in the same U.S. state, subject to the same laws and regulations administered by the same agencies. In addition, the more laggardly environmental performer appears to have had more economic resources at its disposal than the leading mill. The laggard mill was part of a larger 
exemplary mill was located on the waterfront of a fairly large city, once heavily dependent on trade in forest products, but now with a much more diversified economic base. The mill was visible to the white-collar workforce in nearby downtown office buildings. The city was also home to several environmental groups that paid close attention to the quality of the mill's receiving water. The laggard mill, in contrast, was the primary employer in a small company town, miles from the nearest large city. While it experienced some local complaints (from owners of high-priced vacation homes), for the most part its more isolated location buffered it from community or environmental group pressure. The managers at this mill did not perceive themselves to be vulnerable to local pressures anything like those experienced by the leading mill, nor had they come close to establishing the same level of communication or dialogue with environmental groups or regulators. Thus, each mill's social license appears to have been a very important reason for their disparate environmental performance.

However, corporate response to the terms of the social license is not entirely predictable, because the terms of the license may themselves be ambiguous or uncertain, giving rise to the possibility of variable interpretation and action on the part of mill and corporate management. For example, health effects may be unknown or unpredictable, giving rise to uncertain public expectations. Obnoxious odors may be anathema to affluent and middle-class communities but may be regarded as "the smell of money" in communities with little industry and employment. The issues that will concern nearby residents, the special interest groups that will form in a particular location, the strength of those groups, and the alliances they may make are all unpredictable. Consequently, the requirements of the social license are interpreted and responded to differently (and often reshaped) by different corporate managers.

Elsewhere, we have argued that the perceptions and attitudes of mill and corporate management, and their interpretation of their license terms, act as an important filter through which information about the external licenses is sifted and by which their responsiveness to conflicting external pressures is calibrated (Kagan, Gunningham, and Thornton 2003). Hence, environmental management style-the attitudes and modes of thought that guide corporate and mill-level policy, not social pressure alone-is a key variable in determining the capacity of social pressures to shape corporate environmental performance, although quite how corporate management style develops and operates is a complex issue requiring further research.

corporation with more economic depth than the leading mill, and the laggard mill's corporate profitability in the late 1990 s was higher than average for our sample. We have no specific economic data for the leading mill, which was a privately held company. 


\section{Corporate Responses to Social License Demands}

In today's institutional environment, many profit-maximizing companies recognize that they need reputation capital to stay competitive. Reputation capital can reduce uncertainty by managing the risk of adverse social campaigns. Reputation capital also lubricates the regulatory process, providing companies that have good reputations with access to political actors (Sims 2003) and with regulatory flexibility, thereby providing a competitive advantage. Building reputation capital also gives companies far greater control over their own destiny. For example, some managers in our sample, reflecting on past experience, believed they had been largely reacting to the agendas of other stakeholder groups, that they have been unable to anticipate problems, and that the ad hoc solutions generated when they did react often created as many problems as they solved. This assessment led a number of companies to develop proactive strategies for dealing with communities, ENGOs, and governments. One senior corporate official described the situation very bluntly: "Looked at from a business standpoint, it's risk management. We became responsible environmental stewards because it's not in our financial interest to risk operations being closed down." Or as another put it, "Anything that could give you a bad name is an unpredictable risk."

While building reputation capital decreased the risk of unanticipated disruption (as a result of local opposition), a small, unrepresentative opposition might still remain; a single individual might still sue the plant; or having negotiated agreements with the local community, a national ENGO might still demand further changes. While such risks could not be eradicated, the building of reputation capital nevertheless much reduced them, expanding the terms of the firm's social license. So, for example, when Greenpeace sought to launch a campaign against a mill that had done much to build trust with its local community, it received no local support and moved elsewhere.

Different mills in our sample took very different approaches to the issue of meeting their social license and building reputation capital. One or two seemed oblivious to its existence. Some took a strategic approach, such as "buying off" the local community's objections to particular emissions by offering to supply it with better-quality drinking water, or by trying to "win hearts and minds" through public relations campaigns in local schools and with local community organizations. Still others saw their social license and reputation capital as central to their very existence, and hence they had become determined to work directly with stakeholders, to be transparent, and to respond substantially to their concerns. Some companies gradually shifted from defensiveness toward responsiveness to community and NGO concerns, as in the case of one company, whose environmental manager told us, 
Ten years ago we were reacting to threats from the public, from the regulator, and from the greens, and we didn't control the process. We built a virtual wall around ourselves, and no one on the outside was told anything. Now we are going through a process of turning that around, of opening the gates, of an attitudinal change from inside. We went through enormous changes over the years, but we never told anyone, so the only story out there was the green one, that we were engaged in environmental rape and pillage, and it isn't true. So we took stock of real threats, then took the brave step of talking about them, of saying to the public, this is what we've done, and this is what we plan to do ..... Once you start that process, people come down heavy on you, but you need the fortitude to keep going and be totally transparent-we'll show anyone anything. Why? It's the right way to go ..... It comes down to individuals, and over time-trust, listen, and respond.

Similarly, another mill manager noted,

In the old times, we scoped the project, put it together, got board approval, did the costings, brought it back to the board for final costings-then announced what we were going to do. And then maybe the regulators had an inkling; certainly the community didn't. Now, once we have done the preliminary scoping and got the preliminary okay, we brief the community committee, and ask their issues and concerns, then take these on board. They wanted no more effluent, so the challenge was, can we do this and still build the new [installation]? And because we knew this early, we could go to the designers and ask ways to achieve minimum water usage and how to offset this elsewhere in the plant. We achieved this, got environmental approvals from the regulators, and had no objections from the community.

Management at a few mills in our sample, or at their corporate headquarters, were less responsive to social license demands. ${ }^{24}$ Thus, while most companies responded to perceived social license demands by improving their environmental performance, this was not invariably the case, and some reacted to community or NGO demands with resistance rather than

24. There was risk in this strategy, for a mill could not be sure that environmental activists would not be able to prod regulatory license enforcers into action. In the case of Louisiana Pacific's Samoa, California, mill (not in our sample), unresolved complaints by the Surfrider Foundation about the mill's chronic violations of permissible pollution discharges into the ocean resulted in a 1989 lawsuit by that ENGO. The U.S. EPA joined the suit, which resulted in a 1991 consent decree. Louisiana Pacific agreed to install and operate a totally chlorine-free, peroxide-based bleaching system, the first in the United States-thereby going substantially "beyond compliance" with current U.S. law (but positioning itself for compliance with regulations that were likely to be promulgated later in the 1990s) (Norbert-Bohm and Rossi 1998; Young 1993). See also Knickerbocker 1994. 
responsiveness. For example, one company in our sample had considerable reason to pay attention to its local community, because although the company was the major ratepayer in the area, it was not the major employer and was not well regarded. There was a history of environmental damage to the estuary adjacent to the mill, alleged to be "knee deep in dead material in which nothing will grow," and of poor labor relations. Local environmental and community groups were very active in challenging the mill's activities, and they were contemplating legal action on a number of fronts. Community opposition to the proposed opening of a new dump site seemed likely to derail the project, causing the company to spend considerable amounts shipping its waste substantial distances to the next jurisdiction. Despite the presence of this activist community, the mill had a very poor record of community relations. Apart from a fleeting period of dialogue (terminated by the mill management apparently on the instructions of the head office), the general approach had been one of stonewalling, and at the time of our fieldwork, community groups were not welcome at the mill. According to the environmental manager,

This mill has done a horrible job of PR in the last decade. There is a huge trust-chasm with the local community.... odor, particulates, the visual impact: These are legitimate beefs. . . . The track record isn't there. It works against you when things go on behind the community's back.

Yet, for most mills in our sample, social license demands appear to have mattered significantly. They gave corporate officials an additional incentive to comply or even overcomply with the terms of their regulatory license, for legal compliance often served as an important benchmark of company cooperativeness or commitment in the minds of social license enforcers. And social license demands were responsible in many cases for a measure of "beyond compliance" company activity, both in reducing odors and visual impacts and in accelerating the reduction of emissions of chlorinated organics.

\section{INTERACTION BETWEEN SOCIAL AND LEGAL "LICENSES"}

The social license, of course, is not the only influence on corporate behavior. Indeed, the scholarly literature on corporate environmental performance has revolved around the effort to specify other external "drivers" of corporate behavior-not least, regulation and economic forces. However, in the course of our field research we came to regard the concept 
of drivers as somewhat impoverished. It implies the existence of independent, unidirectional and unambiguous pressures, whether from regulation, communities, or markets, that impact on corporations with sufficient force that they react to them. Yet we found that these external factors, rather than being independent, often gain their force through mutual interaction. Indeed, we found it more useful to think not only of social pressures, but also of regulatory and economic pressures, as terms or conditions of a multifaceted "license to operate." In contrast with the image of unidirectional drivers, this concept captures the complexity of the relationship between the regulated enterprise and key stakeholders, and it accords with an important reality we observed: The relationship between the licensors and licensees is interactive, not unidirectional, and many of the license terms are open to interpretation, negotiation, and company-initiated amendment.

As we will see, the interactions among the regulatory, economic, and social strands of the license to operate often intensify the overall constraints under which companies operate. In other cases, however, tensions between the economic, social, and regulatory forces may pull firms in different directions. The economic license, for example, often calls for limits on or even reductions in environmental expenditure, while the terms of the social license push for an increase. Below, we explore the implications of these interactions for the social license, distinguishing for heuristic purposes between legal and social interactions on the one hand, and economic and social interactions on the one other, while recognizing that in the real world all three may interact.

\section{Legal Expansion of the Social License}

The regulatory license often extends the reach and impact of the social license, either by directly empowering social licensors, or by giving them access to information, which they can then use to pressure target enterprises. Conversely, the scope of the legal license can also be expanded as a result of its interaction with the social license-for example, as social pressures on legislators and regulators feed through in terms of enactment, monitoring and enforcement of regulation.

The most common influence of the legal on the social license is that of direct empowerment. For example, the relative power and influence of the local community may be connected directly to the extent to which legislation enables it to participate in decision making about the mill's future. In New Zealand, almost all our respondents emphasized the enormous impact of the Resource Management Act, as it gave individuals the right to make submissions and challenge any variation of the consent (the basic permit or license to operate). As one mill manager described it, "It became a very public process. In 1994-95 there were 169 submissions 
regarding the mill. We had very strong protests. People were finally able to have their say. We had 32 people speaking at the public hearings." This legislation created an environment in which mills had a strong incentive to listen and respond to community concerns; if they failed to do so, they risked delays, possibly for years, in obtaining the consents they needed to introduce technological and other changes.

Laws requiring firm-wide disclosure of environmental information, can also empower local communities, albeit indirectly. The literature on community "right to know" in general and on the U.S. Toxic Release Inventory in particular demonstrates the potential power of informational regulation in this context (Fung, Karkkainen, and Sabel 1998). In Canada, the "environmental score card" published by $\mathrm{BC}$ provincial government, outlining environmental performance indicators and major infringements of regulations, was, according to a pulp mill manager, "a pretty effective tool. If you have recurring environmental problems, you come up on the list. It keeps you in compliance because public pressure is more demanding than the regulatory agencies . . . . agencies are more forgiving."

These examples do not exhaust the list of ways in which the terms of the legal license expand the social license. That also occurs when statutes or regulations grant citizens standing to sue either a company or a regulatory agency, expand access to information, require companies to consult with local communities, or invite advocacy groups to participate in the regulatory or legal decision-making process. In addition to facing criminal sanctions and administrative notices (and in the United States, civil penalties), companies that breach their legal obligations are also vulnerable to either individual or class actions from citizens injured as a result of the facility's illegal activities. Local residents can invoke legal rights, or alleged breaches of them, to delay by both legal and political means any expansion of the facility. For example, they may challenge or oppose variation in a firm's permit requirements, or they may lobby local and state governments to limit any expansion of the mill under planning and land use laws.

Community and environmental groups use compliance (or noncompliance) with regulations to judge a company's compliance with the broader social license. For this reason, some companies fear enforcement not so much because of any penalty the regulator is likely to inflict but rather because enforcement actions generate adverse publicity and, as a consequence, informal sanctions imposed by the public, the media, and perhaps also by markets. For example, in the early 1990s, Greenpeace was highly successful in targeting individual mills in our sample on the basis of their environmental records and marshalling consumer and customer pressure against them. Certainly, compliance with regulation often will not in itself satisfy broader community concerns, which often extend well beyond the standards embodied in regulation or facility permits. However, at the very least, substantive noncompliance with the permit and regulation sends 
signals to the community concerning the company's failure to discharge its overall social and environmental obligations.

\section{Social Expansion of the Legal License}

While the terms of the legal license commonly expand the scope of the social, the converse is also true. For example, a failure to respond appropriately to the social license involves the risk of a tighter regulatory license, as politicians and ultimately regulators respond to community dissatisfaction. As one senior corporate official from a firm in our sample pointed out, "Local communities have the ability through the political process to create the regulations that allow you to do business . . . . we operate under a license from the public in every place we do business, so we have to be sensitive to public concerns." Again, so sensitive are some companies to the messages they send to local communities that they are willing to compromise substantially on the terms of their legal license and permit conditions. Thus, as another company official recounted,

When dioxin first showed up in 1991 when we renewed our waste water permit, there were concerns from the community that a deal was done between the company and the government behind closed doors. We didn't like the permit limit, but we didn't want to appeal it because that would send [the] wrong message to the community. We had some trust to build up. We didn't want to appeal the permit for that reason. We asked, what do you want in the permit - and so sent a message out and saved our reputation [with the community]. The public has ability to appeal the permit. Nobody appealed it, but [it] was very controversial. Every other pulp company in the state appealed their permit.

However, we also found that mills sometimes use compliance with the social license to gain respite from some of the terms of the regulatory license. For example, good community relations can sometimes be used to gain additional regulatory leverage. As one environmental manager argued, "If you can sell something to the local community, they will stand in front of the regulators on your side." This manager gave the example of a dispute between the regulator and the mill concerning a Superfund site. Although the company wanted to proceed with a cleanup plan, the government was reluctant to sign off on anything. "[B]ut the environmental groups mobilized behind us, and that got EPA and [the state regulator]in the room, and to achieve the first settlement of Superfund site in the country without litigation .... it saved us millions of dollars."

More broadly, the way enforcement agencies exercise their discretion may be influenced substantially by community mores and expectations. On 
occasion, regulatory action could even be viewed as a surrogate for community action, with the company regarding their main license as social rather than regulatory. For example, in the Australian case cited earlier, the regulator did not appear to prosecute simply in response to a breach of environmental standards. Rather, it did so only when the level of community complaints about a particular incident was adjudged to be sufficiently high.

\section{THE LIMITS OF THE SOCIAL LICENSE}

We have argued that today, at least in economically advantaged democracies, many corporations no longer perceive their social obligations as necessarily synonymous with their legal obligations, and that the conditions demanded by social actors may be tougher than those required by law, resulting in beyond-compliance corporate behavior. But clearly there are limits to how far beyond compliance companies are able and willing to go, and the degree to which social actors can effectively impose their demands on companies reluctant to meet them. The limitations of the social license arise from each of the three sectors already discussed: social, legal, and economic. First, in order to articulate social demands, social actors must be able to determine that a harm has or might well occur and must also have the organizational competence to develop and effectively articulate demands to address the harm. Second, legal and political actors must be reasonably responsive to social actors' demands; that is, they must see the demands of social actors as both important and legitimate. Finally, economic concerns often constrain the degree of beyond-compliance behavior firms are willing or able to undertake.

\section{Social Actors}

While obnoxious odors or visible dumps or emissions to the air or water are easily detected and can form the basis for rallying and organizing social actors, other kinds of environmental harms are less detectable or harder to trace to particular businesses. In such cases, the terms of the social license may be much less stringent. Of course, even when discharges are not detectable by human sensors, they may be made detectable by scientists or technicians. But even if those data are available, much depends on the social interpretation of their meaning. For example, advances in analytical chemistry that allowed the detection of even low levels of dioxin in pulp mills' water effluents triggered social activism only because of the preexisting publicity concerning dioxin's toxic effects.

Had this general awareness been absent, finding dioxin in pulp mill discharges would have resulted in a small footnote in an obscure scientific 
journal rather than a rallying cry for an effective Greenpeace campaign. Where the general knowledge and public concern about particular adverse environmental terms are at lower levels, firms' social license demands may lie dormant. Once aware of a harm, communities must be able to develop and articulate a set of demands designed to mitigate or redress it. The development of demands seldom requires a high degree of competence; most often it simply insists that the firm cease and desist or "do something about it." However, the ability to come to an agreement as to what the harm is and what the appropriate demands in response to it should be requires a degree of organizational competence that may be absent in more marginal, disorganized communities or in less developed countries. ${ }^{25}$ Similarly, once developed, demands must be articulated in a manner that encourages other social, legal, and economic actors to understand and respond to them. Incompetent articulation of demands can also result in delegitimation of social demands as extremist or irrational, and poor communities can be disadvantaged in this regard too.

The imbalance of economic power between companies and local communities may also weaken social license pressures. For example, the company town syndrome is well documented. Where there is a single major employer on which the local community depends heavily, not just for jobs but also for its broader economic well-being, criticism tends to be extremely muted. Two of the mills in our sample were located in company towns in this sense. Neither had good environmental records, and neither had experienced community opposition to their environmental record. Imbalance of power is also at the core of recent findings by Bandyopadhyay and Horowitz (forthcoming) that poor communities have higher predicted violation rates.

\section{Political/Legal Actors}

As already discussed, the terms of the social license often are enforced indirectly through economic or legal mechanisms. In undemocratic regimes, officials and politicians may feel no pressure if they fail to respond to public concerns. Thus, the type of political regime in a jurisdiction may affect the strength of social license demands. Similarly, where agencies have been captured by industry, the demands of social actors may go unheeded. For example, in a previous study, one of us found that a very close relationship

25. See further Davy 1997. Foster (1998) makes the broader argument that achieving environmental justice for poor communities will also require a move from the current pluralistic, interest-group model of participation (which in practice tends to silence some groups) to one involving shared knowledge, collective decision making, and free and equal discourse among participants. As her careful case study also demonstrates, such a move itself presents enormous challenges. 
between the owners of an asbestos mine and local regulators enabled both sets of officials to ignore workers' and community complaints (notwithstanding levels of asbestos dust that grossly exceeded the prescribed limits), and regulators routinely gave the company prior warning of inspections (Gunningham 1987).

The importance of the harm, or indeed its very existence, may also be contested. For example, some regulatory officials might regard smelly odors emanating from pulp mills to be simply a nuisance and not an urgent object of government action, overriding the fear of some neighbors that such odor may itself be an indicator of some more serious health hazard (MoragLevine 1994).

In other cases, government or corporate decision makers may be more concerned about the economic consequences of a social demand than its health or environmental benefits, especially where such benefits are contested. Thus, where the economic costs of social demands are high, and the health and environmental benefits are small, uncertain, or contested, legal and political actors are likely to be less responsive to social pressures. For example, one of the Canadian mills in our sample chose to ignore community concerns relating to unsightly effluent left drying on the banks of the river downstream. The company asserted that the environmental impact was minimal (a view shared by the local regulators), and it was prepared to ignore strong criticism from a local community group, confident that neither the group nor the community more generally had sufficient political or legal leverage (or independent scientific evidence) to inflict significant economic or reputational damage.

\section{Economic Actors}

As already noted, the terms of the social license usually can only be enforced indirectly through economic or legal mechanisms. The principal economic enforcement mechanism is the boycott, which may be carried out by any number of economic actors-customers, clients, ultimate consumers, investors, or shareholders. Boycotts, however, may be impossible to organize or less effective against companies that are less concerned about their reputation, either because they do not have a consumer market or branded identity to protect, or because the harm is not associated with a product directly, but rather with a by-product of the production process. For example, environmental activists were able to generate concern regarding pulp mills' use of chlorine partly because dioxin was present in certain consumer products-diapers, coffee filters, and tampons. Dioxin was not simply a by-product of diaper production, discharged in a remote place to affect a distant ecosystem. But more typically, when the harm is associated with the only production process and not the product produced, 
social license demands are less effectively enforced through economic mechanisms.

Although the economic license can sometimes be used to enforce the demands of social actors, our pulp industry research suggests that the economic license more prominently served as a brake on very costly "beyond compliance" environmental initiatives, particularly those that could not be justified in margin-of-error or win-win terms. The lesson is hammered home by the experience of firms that suffered economically from overestimating the stringency of anticipated regulations or the eagerness of customers to buy "greener" products. Reinhardt relates the experience of Champion, a paper-products company that in the high-pulp-price era beginning in the late 1980s adopted an "aggressive strategy [including the expenditure of $\$ 1$ billion on environmental technologies and systems] for managing both regulatory risk and the business risk inherent in antagonistic relations with downstream neighbors" (2000, 152-54). This strategy included the expenditure of $\$ 330$ million in its Canton, North Carolina, mill. The mill's chlorinated organic emissions went down to $0.1 \mathrm{~kg}$ per ton, far lower than current law or EPA's mid-1990s rule eventually required. But by then pulp prices had declined, and the mill had very large capital cost burdens compared to its competitors. In 1999, Champion sold the mill to its employees, managers, and a New York investment fund.

Consider, too, the experience of a Canadian firm that made an earlier and larger investment in totally chlorine free (TCF) technology than most of its industry peers. The anticipated demand and price premium for TCF pulp did not materialize. The mill ended up losing money, and the company came to be perceived by other pulp mill managers as an example of how not to proceed. The corporate managing director was replaced, and his successor reintroduced the conventional emphasis on short-term economic targets (although the mill did continue to be a leader in most measures of effluent control).

Understandably, few firms were eager to follow the environmental technology path blazed by such facilities. As long as customers continued to care more about cost, brightness, and strength of their paper than about the pulp mills' chlorinated organic numbers, most mills used regulatory requirements as their chief guide to environmental performance. Moreover, they treated these economic license constraints as fairly fixed. They did not strive to generate more customer demand for unbleached or less bright paper in order to reduce the environmental impact of unrecycled bleaching chemicals in their effluent.

As interpreted by the enforcers of the economic license-investors, lenders, and financial analysts-the economic license does not encourage a firm to invest in very costly environmental measures or technologies that do not improve productivity and profits unless government regulations assure that the firm's competitors will be compelled to make similar expenditures. 
As Forest Reinhardt has pointed out $(2000,25,28)$, customers in markets for "commodity products" (such as pulp) usually will pay premiums for environmentally differentiated products only if the products lower their own overall costs. And even then a marketer of "greener" products will not benefit if its competitors can easily replicate the same innovation. Thus, early movers to ECF pulp derived little benefit, since most of their competitors, anticipating regulatory tightening, quickly did the same. In general, then, social license demands are likely to be more limited in industries and companies that produce commodity products.

\section{CONCLUSION: SOCIAL LICENSE AND ENVIRONMENTAL POLICY}

The environmental demands of social actors, the "social license" of an industrial facility, can exceed the facility's regulatory requirements and induce the firm to do more for the environment than required by the law. This occurs as a matter of risk management: Facility and company managers believe that not meeting the requirements of the social license will ultimately result in increased regulation or greater economic costs to the company, although the extent to which they believe this and their estimates of costs might vary.

In our pulp industry research, we found that the social license is monitored and enforced by a variety of social stakeholders who commonly seek leverage by exploiting a variety of license terms. Environmental groups not only enforce the terms of the social license directly (e.g., through shaming and adverse publicity) but also seek to influence the terms of the economic license (e.g., generating consumer boycotts of environmentally damaging products) and of the regulatory license (e.g., through citizen suits or political pressure for regulatory initiatives). Thus the interaction of the different types of license often exceeds the effect of each acting alone. The terms of some legal license provisions extend the reach and impact of the social license by directly empowering social activists or by giving them access to information that they can use to pressure target enterprises. Conversely, a company which fails to respond appropriately to social license obligations risks a tightening of its regulatory license, as frustrated community activists turn for help to politicians and regulators. At the same time, the interaction between a firm's economic license and the demands of social stakeholders helps determine how far a firm will go beyond legal compliance.

These findings have important policy implications, for they suggest that business firms' social licenses provide a particularly powerful point of leverage. Community and environmental advocacy groups can act as 
effective watchdogs and de facto regulators, shaming and otherwise pressuring companies into beyond-compliance environmental performance. ${ }^{26}$ While they can sometimes play this role in the absence of any form or state intervention, their effectiveness, we have observed, is enhanced by various forms of facilitative government regulation.

A number of statutory provisions, of course, already allow community and environmental groups to play such a role: provisions that authorize citizen suits against firms, compliance certification requirements in major permit programs and information disclosure provisions such as the Toxic Release Inventory. Such initiatives could be further expanded. For example, permit conditions could be further modified so as to enhance the community's capacity to participate, not just on environmental compliance issues but also in assessing the aggregate or cumulative environmental risks posed by the business and formulating next-phase strategies for reducing them (Lazarus and Tai 1999). And broader public-process reforms may also be desirable, as when legislators contemplated requiring EPA to provide "early, direct and meaningful community involvement in each significant phase of the response activities taken under the Act" (Foster 1998). But beyond the general desirability of greater community empowerment, two modes of facilitative regulation appear particularly important: procedural empowerment and comparative information.

\section{Procedural Empowerment}

Our research suggests that government actions that procedurally empower social actors to consult about (and hence to delay) changes to facility infrastructure or operations would be particularly potent in influencing corporate environmental behavior. Such actions include requiring facilities to respond formally to community concerns, plus regulatory or judicial review of the response if it is deemed by the community to be arbitrary and capricious. In New Zealand, mills reported having become much more responsive to community environmental concerns after communities were

26. For example, in Indonesia, under the PROPER PROKASIH program, regulators rank the performance of individual facilities using surveys, a pollution database of team reports, and independent audits. An enterprise's pollution ranking is readily understood by the public, being based on a color coding (gold and green for the best performers; black, blue, and red for those not in compliance). The program has reportedly been very successful in improving the environmental performance of participating firms (see Afsah and Vincent 1997). In our study, we found that in British Columbia, mills were particularly mindful of avoiding breaches that might result in poor standing in a periodic government-published report that functioned much as a mill-by-mill environmental scorecard. In the United States, the Toxic Release Inventory, which simply obligates firms to publish their total estimated emissions of potentially hazardous chemicals, has created strong incentives to reduce the use of such chemicals. 
given the legal right to challenge the terms of each facility's "consent" (permit), and thereby gained the power to delay the introduction of new processes or technology. In an Australian jurisdiction, similar effects flowed from a new law that obligated firms to prepare and comply with an environmental improvement plan, including a commitment to consultation with local communities (see, further, Gunningham and Sinclair 2002). In Canada and the United States, the permitting process has long been open to the public and allowed for public comment on permitting decisions. Such public access has been extended in the United States through programs such as Project XL and the Environmental Leadership Program, which make corporate reporting to and consultation with local communities a condition for providing a facility greater regulatory flexibility.

However, procedural empowerment raises two important concerns. First, a badly designed process could be hijacked by small extremist elements, able to delay actions that most in the community or the country support. Procedural empowerment would have to provide a mechanism that allows more broadly based coalitions to block extremist delaying tactics. This mechanism would encourage companies to invest in community relations so as to obtain sufficient reputation capital to overcome extremist attacks. Second, the process could be hijacked by well-meaning incompetents, more concerned with phantom threats than real ones, or with impossibly expensive demands. But once again, real outreach and investment in the community seems likely to minimize this risk.

\section{Comparative Information}

While current regulation often requires companies to report environmental information, this information is not usually designed to be explicitly comparative and allow the lay public to rank facilities in terms of their environmental performance. ${ }^{27}$ The Toxic Release Inventory permits cursory comparisons, but the quality of the data and a host of other problems detract from its usefulness (see Cohen 2001). ${ }^{28}$ Explicitly comparative information dramatically increases the social meaning of environmental information because it identifies both the leaders in an environmental arena and the laggards. It therefore provides incentives to the best performers to do better,

27. Instead, information is often designed to determine whether legal limits or other requirements have been met, not whether they have been met more quickly, more efficiently, or more completely than others.

28. Although the TRI is explicitly comparative, it is better at comparing a facility's current practice to its previous practice than comparing different facilities. The vast majority of information standards are those that require facilities to monitor their air emissions and water discharges. These requirements are not explicitly comparative. Neither are requirements to submit reports and figure out best management practices. 
and to the worst performers to improve because leaders can be rewarded for their excellence while laggards can be punished. In addition, comparative information standards might well work in circumstances where enforcement is weak, political officials unresponsive, and regulators overwhelmed, because they make it easy to target laggards (and reward leaders) in the market.

Beyond all else, our research demonstrates that corporate environmental behavior cannot be explained purely in terms of instrumental and moral obligations to comply with the law. On the contrary, in an increasing range of circumstances, at least in reputation-sensitive industries, corporations contemplate going beyond compliance for reasons more closely connected with the perceived terms of their social license, even if the extent to which they do so may be constrained by economic considerations.

\section{REFERENCES}

Asfah, S., and T. Vincent. 1997. Putting Pressure on Polluters: Indonesia's PROPER Program. Harvard Institute for International Development. http://www.worldbank .org/nipr/workpaper/Vincent.

Bandyopadhyay, S., and Horowitz, J. D. Forthcoming. Randomness in Point-Source Water Pollution: Evidence and Implications.

Baylis, R., L. Connell, and A. Flynn. 1998. Sector Variation and Ecological Modernization: Towards An Analysis at the Level of the Firm. Business Strategy and the Environment 7: 150-61.

Becker, Gary. 1968. Crime and Punishment: An Economic Approach. Joumal of Political Economy 76: 169-217.

Cohen, Mark A. 2001. Information as a Policy Instrument in Protecting the Environment: What Have We Learned? Environmental Reporter 32:10425-431.

Connor, Tim, and Jeff Atkinson. 1996. Sweating for Nike: A Report on Labour Conditions in the Sport Shoe Industry. Oxfam Community Aid Abroad Briefing Paper, No. 16. www.caa.org.au/campaigns/nike/sweat2.html.

Davy, B. 1997. Essential Injustice. New York: Springer 1997.

Florida, R., M. Atlas, and M. Cline. 1999. What Makes Companies Green? Paper presented to the 95th Annual Meeting of the Association of American Geographers, Hawaii, March.

Foster, S. 1998. Justice from the Ground Up: Distributive Inequities, Grassroots Resistance, and the Transformative Politics of the Environmental Justice Movement. Californian Law Review 86:775-841.

Fung, A., B. Karkkainen, and C. Sabel. 1998. After Backyard Environmentalism: Towards a New Model of Information-Based Environmental Regulation. Paper prepared for Conference on Information-Based Environmental Regulation, Columbia University, New York.

Ghobadian, A., H. Viney, J. Lui, and P. James. 1998. Extending Linear Approaches to Mapping Corporate Environmental Behaviour. Business Strategy and the Environment 7:13-23.

Greening, D., and B. Gray. 1994. Testing a Model of Organizational Response to Social and Political Issues. Academy of Management Joumal 37 (3):467-98. 
Gunningham, Neil. 1987. Negotiated Non-compliance: A Case Study of Regulatory Failure. Law and Policy 9 (1):69-91.

Gunningham, Neil, Robert A. Kagan, and Dorothy Thornton. 2003. Shades of Green: Business, Regulation, and Environment. Stanford, Calif.: Stanford University Press.

Gunningham, Neil., and D. Sinclair. 2002. Leaders and Laggards: Next Generation Environment Protection. Sheffield, U.K.: Greenleaf.

Hawkins K., and B. Hutter. 1993. The Response of Business to Social Regulation in England and Wales. Law and Policy 15:199-218.

Hoffman, A. 1997. From Heresy to Dogma: An Institutional History of Corporate Environmentalism. Stanford, Calif.: Stanford University Press.

Joyce, S., and I. Thomson. 1999. Earning a Social License to Operate: Social Acceptability and Resource Development in Latin America. Mining Joumal, 11 June, 441.

Kagan R, N. Gunningham, and D. Thornton. 2003. Explaining Corporate Environmental Performance: How Does Regulation Matter? Law and Society Review 37:51-90.

Knickerbocker, Brad. 1994. Making Paper Safer for the Environment. Christian Science Monitor, 12 April.

Lazarus, R. J., and S. Tai. 1999. Integrating Environmental Justice into EPA Permitting Authority. Ecology Law Quarterly 26:617-78.

Magat, Wesley, and W. Kip Viscusi. 1990. Effectiveness of the EPA's Regulatory Enforcement: The Case of Industrial Effluent Standards. Joumal of Law and Economics 33:331-60.

McClelland, J. D., and J. K. Horowitz. 1999. The Costs of Water Pollution Regulation in the U.S. Pulp and Paper Industry. Land Economics 75(2):220-32.

Miller, J. L., and A. B. Anderson. 1986. Updating the Deterrence Doctrine. Joumal of Criminal Law and Criminology 77:418-38.

Moore, Julia. 2001. Frankenfood or Doubly Green Revolution: Europe vs. America on the GMO debate. In AAAS Science and Technology Policy Yearbook, ed. A. H. Teich, S. D. Nelson, C. McEnaney, and S. J. Lita. Washington, D.C.: American Association for the Advancement of Science. http://www.aaas.org/spp/rd/ch14.pdf.

Morag-Levine, Noga. 1994. Between Choice and Sacrifice: Constructions of Community Consent in Reactive Air Pollution Regulation. Law and Society Review 28:1035-77.

Nash, J. 2000. Voluntary Codes of Practice: Non-Governmental Institutions for promoting Environmental Management in Firms. Paper given at National Academy of Sciences/National Research Council Workshop on Education Information and Voluntary Measures in Environmental Protection Washington, D.C., November.

Neale, A. 1997. Organizational Learning in Contested Environments: Lessons from Brent Spar. Business Strategy and Environment 6:93-103.

Norbert-Bohm, Vicki, and Mark Rossi. 1998. The Power of Incrementalism: Environmental Regulation and Technological Change in Pulp and Paper Bleaching in the U.S. Technology Analysis and Strategic Management 10:225-41.

Porter, M. and C. Van der Linde. 1995. Green and Competitive: Ending the Stalemate. Harvard Business Review 73:120-34.

Prakash, A. 2000. Greening the Firm: The Politics of Corporate Environmentalism. Cambridge, U.K.: Cambridge University Press.

Regens, James L., Barry J. Seldon, and Euel Elliott. 1997. Modeling Compliance to Environmental Regulation: Evidence from Manufacturing Industries. Joumal of Policy Modeling 19(6):683-96.

Reinhardt, F. 2000. Down to Earth. Cambridge, Mass.: Harvard Business Press. 
Sonnenfeld, David A. 2002. Social Movements and Ecological Modernization: The Transformation of Pulp and Paper Manufacturing. Development and Change 33(1):1-27.

Stanley, E. 1999. Available Environmental Data for Deterrence Research. Presentation by EPA Office of Compliance at Forum on Deterrence of Environmental Violations and Environmental Crimes, National Institute of Justice Washington, D.C., 12 July.

Stigler, George. 1970. The Optimum Enforcement of Laws. Joumal of Political Economy 78:526-36.

Van Yoder, Steven. 2001. Beware the Coming Corporate Backlash. Industry Week, 2 April, 38-42.

Wright, M. 1998. Factors Motivating Proactive Health and Safety Management. Contract Research Report prepared by Entec U.K. Ltd. for the Health and Safety Executive London, Her Majesty's Stationery Office.

Yosie, T., and T. Herbst. 1997. The Journey Towards Corporate Environmental Excellence: Integrating Business Methods with Environmental Management. Center for Strategic and International Studies. http://www.csis.org/e4e/yosierpt.html.

Young, J. 1993. Louisiana-Pacific's Samoa Mill Establishes TCF Pulp Production. Pulp and Paper 67:61-63. 
$* * *$

HeinOnline -- 29 Law \& Soc. Inquiry 3422004 